\title{
The Role of Phosphorus as an Abscission-inducing Agent for Olive Leaves and Fruit
}

\author{
Kiyoshi Banno', George C. Martin, and Robert M. Carlson \\ Department of Pomology, University of California, Davis, CA 95616 \\ Additional index words. Olea europaea, $\mathrm{P}$ compounds
}

\begin{abstract}
Citrate-phosphate buffer induced olive (Olea europaea L.) leaf abscission at pH 3, 5, or 7. Of several sources of $P$-induced leaf abscission, $\mathrm{NaH}_{2} \mathrm{PO}_{4}$ was the most effective. Sensitivity to $\mathrm{P}$ was shown by leaf abscission, leaf desiccation, or both among 32 species representing 22 genera. Applied $P$ accumulates in petioles, but its effect on abscission does not seem to depend on ethylene production. The low $P$ content in the ethephon molecule may have an additive effect in ethephon-induced abscission. Stem-fed $\mathrm{NaH}_{2} \mathrm{PO}_{4}$ or ethephon resulted in total leaf and fruit abscission. Of the chemicals applied as a foliar treatment, only $\mathrm{NaH}_{2} \mathrm{PO}_{4}$ caused fruit abscission with minimal leaf loss. Adding $\mathrm{Al}_{2} \mathrm{O}_{3}$ to adsorb $\mathrm{P}$ in treatment solutions delayed the abscission effect of ethephon and $\mathrm{NaH}_{2} \mathrm{PO}_{4}$. Adding glycerol to $\mathrm{NaH}_{2} \mathrm{PO}_{4}$ increased fruit abscission from $50 \%$ to $\approx 80 \%$ and leaf abscission from $\approx 9 \%$ to $18 \%$. The presumed effect of glycerol is from slowing the drying rate and thereby increasing $P$ penetration into the fruit abscission zone. The pedicel-fruit cavity is a collection basin for spray accumulation that is not present in the leaf petiole attachment to the stem. This morphological difference probably leads to greater absorption of abscission-inducing materials by fruit. Chemical name used: (2chloroethyl)phosphonic acid (ethephon).
\end{abstract}

Ethephon is the most widely used ethylene-releasing compound in agriculture to induce fruit abscission (Ben-Tal and Lavee, 1976; Daniel and Wilkinson, 1972; Martin et al., 1981). Mechanically harvesting olives removes only $60 \%$ of the fruit, an unacceptable degree of removal. Also, the remaining fruit lead to alternate bearing. For olive, all ethylene-releasing compounds, including ethephon, have been tested extensively as fruit looseners for mechanical harvest, but their acceptance for olive has been precluded because of excessive leaf loss (Martin et al., 1981). Leaf loss in olive at harvest leads to the entry of olive knot bacteria (Pseudomonas syringae pv. savastanoi), reduced crop the next year, and tree decline (Martin, 1986).

Potential fruit- and leaf-abscission-inducing chemicals are tested routinely in our laboratory using an olive explant system. Olive shoots containing six nodes and 12 leaves are taken from shoots in the field and placed with their cut ends in vials of solution for testing (Lang and Martin, 1985). Using the explant system, we accidentally found that citrate-phosphate buffer induced leaf abscission. This serendipitous finding has led to extensive investigations into new strategies for obtaining olive fruit abscission. The purpose of this investigation was to identify the abscissioninducing agent in citrate-phosphate buffer; explore its range of influence on several species, including our target species Olea europaea; and explore the mechanism of abscission.

\section{Materials and Methods}

Vegetative shoots of 'Manzanillo' olive were collected as needed from the field during the growing season at the Univ. of California, Davis. Excised shoots were placed immediately in buckets of water so that cut ends were immersed for transport to the laboratory. There, shoots containing six nodes with pairs of 1 -year-old leaves were cut under water to $\approx 20 \mathrm{~cm}$ long and placed

Received for publication 1 Oct. 1992. Accepted for publication 15 Jan. 1993. The cost of publishing this paper was defrayed in part by the payment of page charges. Under postal regulations, this paper therefore must be hereby marked advertisement solely to indicate this fact.

'On sabbatical. Current address: Faculty of Agriculture, Tottori Univ., Tottori 680, Japan. into 50-ml test tubes of either distilled water or treatment solutions.

Phosphorus-induced leaf abscission using stem-fed explants. In the $\mathrm{pH}$ experiment, citrate-phosphate buffer solutions were mixtures of $100 \mathrm{~mm}$ citric acid and $200 \mathrm{~mm} \mathrm{NaH} \mathrm{PO}_{4}$ to achieve $\mathrm{pH}$ 3.0, 5.0, and 7.0. In the initial experiments, citrate-phosphate buffer induced leaf toxicity and extensive defoliation; thus, all subsequent experiments reported here were conducted at $10 \%$ of the original strength $\left(10 \mathrm{~mm}\right.$ citric acid and $20 \mathrm{~mm} \mathrm{NaH}_{2} \mathrm{PO}_{4}$.

To clarify which component of the citrate-phosphate buffer caused abscission, citric acid and $\mathrm{NaH}_{2} \mathrm{PO}_{4}$ were tested separately at $0.25,2.5$, and $25 \mathrm{~mm}$. After finding that $\mathrm{NaH}_{2} \mathrm{PO}_{4}$ was the active component, sodium chloride, sodium carbonate, monobasic calcium phosphate, and monobasic potassium phosphate were compared at $0.25,2.5$, and $25 \mathrm{~mm}$ to determine which ion in $\mathrm{NaH}_{2} \mathrm{PO}_{4}$ induced leaf abscission. Solution $\mathrm{pH}$ was adjusted routinely to 5 with $0.1 \mathrm{~N} \mathrm{HC} 1$.

In the stem-fed explant system, $200 \mathrm{mg}$ ethephon/liter $(\approx \mathrm{pH} 3.0)$ resulted in complete leaf abscission within a few days. Leaf abscission with ethephon at $200 \mathrm{mg} \cdot$ liter $^{-1}$ was compared with 25 mM NaH $\mathrm{PO}_{4}$, and each compound was tested further by adding $500 \mathrm{mg} \mathrm{Al}{ }_{2} \mathrm{O}_{3} / \mathrm{ml}$ to adsorb phosphate (Elliot et al., 1983). $\mathrm{Al}_{2} \mathrm{O}_{3}$ is not soluble in water, and the ratio of solid to solution provides a superabundant surface for adsorption of phosphate at $25 \mu \mathrm{M}$ inorganic P (Elliot et al., 1983).

The location of $\mathrm{P}$ accumulation in the explants was estimated by measuring total $\mathrm{P}$ after acid digestion (Skinner et al., 1987). Phosphorus content was compared in stem bark and wood and in leaf petioles and blades during the first 4 days of $P$ stem feeding. The notion that $\mathrm{P}$ may induce leaf abscission via elevated ethylene production was tested by measuring ethylene daily in P-treated explants (Lavee and Martin, 1981a).

The range of P-induced leaf abscission was tested on 22 genera representing 32 tree species using $25 \mathrm{~mm} \mathrm{NaH}_{2} \mathrm{PO}_{4}, \mathrm{pH} \mathrm{5}$, stem-fed to excised shoots during the last week of Sept. 1991. Each shoot without fruit or flowers was cut to $\approx 25 \mathrm{~cm}$ long, placed in water, carried to the laboratory, recut under water, and placed in a vial containing phosphate. Leaf abscission was evaluated for 10 days.

Phosphorus-induced leaf and fruit abscission using stem-fed and foliar-sprayed explants. Olive explants maintain water use and "normal" appearance for 7 days in the laboratory. By day 10, 
however, the explants take up little water per day, begin to show leaf chlorosis, and leaf abscission may begin. All experiments reported in this segment were terminated 7 days after treatment so that comparisons of treatment effects would be made before control explant deterioration was apparent.

Fruiting shoots of 'Manzanillo' olive were collected and treated monthly starting from middle Aug. to early Oct. 1991. Shoots containing six nodes and six to eight fruit were chosen and recut under water to $\approx 20 \mathrm{~cm}$ long and placed into 50 -ml test tubes as described before.

Olive leaf and fruit abscission rates in stem-fed explants were compared among 2.5 and $25 \mathrm{~mm} \mathrm{NaH}_{2} \mathrm{PO}_{4}, 200 \mathrm{mg} /$ liter ethephon, $200 \mathrm{mg}$ ethephon/liter with ethylene removed (ethephon at $\mathrm{pH} 7$ adjusted with $\mathrm{NaOH}$ ), and $200 \mathrm{mg}$ ethephon/liter with $500 \mathrm{mg}$ $\mathrm{Al}_{2} \mathrm{O}_{3} / \mathrm{ml}$ to adsorb phosphate.

Sodium dihydrogen phosphate at several concentrations was applied as a foliar spray to the fruiting shoots with $0.25 \%$ Regulaid (Kalo Agricultural Chemicals, Petaluma, Calif.) added as a wetting agent. Adding $1 \%$ glycerol in the spray solution was tested to prolong drying time and promote phosphate penetration (Fisher and Walker, 1955), and two sprays (separated by $4 \mathrm{~h}$ ) of $\mathrm{NaH}_{2} \mathrm{PO}_{4}$ at $50 \mathrm{~mm}$ were compared to one spray at $100 \mathrm{~mm}$. In a final experiment, one droplet $(\approx 30 \mu \mathrm{l})$ of $200 \mathrm{mg}$ ethephon/liter or 100 mM NaH${ }_{2} \mathrm{PO}_{4}$ was applied to the pedicel-fruit cavity and the leaf axil, and the leaf and fruit abscission response was compared to that obtained with foliar sprays of $200 \mathrm{mg} /$ liter ethephon and 100 $\mathrm{mM} \mathrm{NaH}_{2} \mathrm{PO}_{4}$.

In each experiment, 12 replications were used in a randomized complete-block design. Leaf and fruit abscission was determined daily by touching the explants lightly with a finger. All data were tested by analysis variance and the means were compared by Duncan's multiple range test.

\section{Results and Discussion}

All initial experiments were continued until all leaves abscissed.

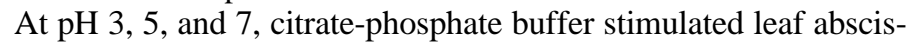
sion compared with the control, but there was no significant difference among the citratephosphate buffer treatments (Fig. 1). Although no evidence was found for $\mathrm{pH}$ to influence abscission, it was unclear which component (citric acid or $\mathrm{NaH}_{2} \mathrm{PO}_{4}$ ) of the buffer solution induced abscission. A comparison at three concentrations showed that $\mathrm{NaH}_{2} \mathrm{PO}_{4}$ influenced leaf abscission more than citric acid (data not shown). Citric acid up to $2.5 \mathrm{~mm}$ did not

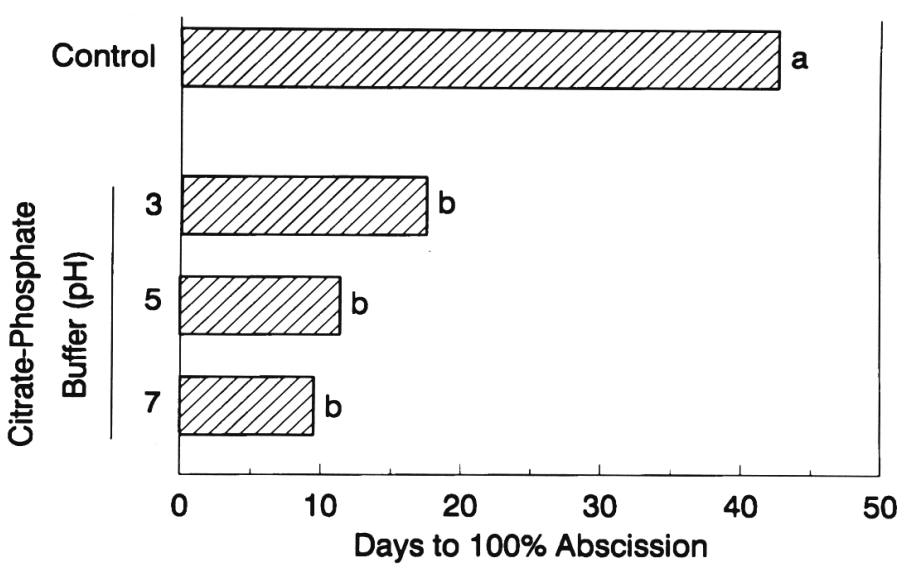

Fig. 1. Effect of stem feeding citrate-phosphate buffer at three $\mathrm{pHs}$ and a $\mathrm{pH} 5$ water control on 'Manzanillo' olive leaf abscission from excised shoots. Mean separation by Duncan's multiple range test at $P \leq 0.05$.

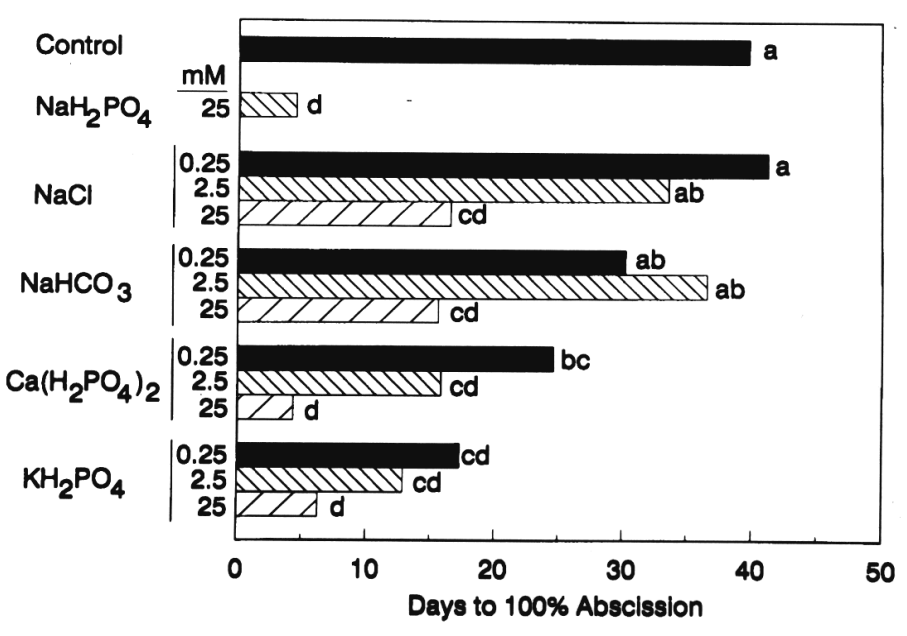

Fig. 2. Effect of stem feeding several $\mathrm{Na}$ and phosphate compounds on leaf abscission from excised 'Manzanillo' olive shoots; $\mathrm{pH}$ of all solutions was adjusted to 5 . Mean separation by Duncan's multiple range test at $P \leq 0.05$.

significantly affect leaf abscission in the controls, whereas even $0.25 \mathrm{~mm} \mathrm{NaH}_{2} \mathrm{PO}_{4}$ significantly induced leaf abscission more than citric acid or control treatments.

Table 1. Leaf abscission response to $25 \mathrm{mM} \mathrm{NaH}_{2} \mathrm{PO}_{4}$ stem-fed to excised shoots of selected tree species.

\begin{tabular}{|c|c|c|c|}
\hline $\begin{array}{l}\text { Leaf desiccation and death, } \\
\text { no abscission }\end{array}$ & $\begin{array}{l}\text { Leaf desiccation } \\
\text { and abscission }\end{array}$ & $\begin{array}{l}\text { Leaf abscission without } \\
\text { desiccation }\end{array}$ & $\begin{array}{l}\text { No leaf desiccation or } \\
\text { abscission, but white } \\
\text { exudate from leaf petiole }\end{array}$ \\
\hline Eucalyptus polyanthemos Schauer & Celtis occidentalis L. & Actinidia chinensis Planch. & Buxus microphylla Siebold and Zucc. \\
\hline Ficus carica $\mathrm{L}$. & Diospyros kaki L.f. & Feijoa sellowiana O. Berg & Euonymus japonica Thumb. \\
\hline Juglans hindsii Jeps. & Eriobotrya japonica (Thumb.) Lindl. & Olea europaea L. & Ginkgo biloba L. \\
\hline Liriodendron turipifera $\mathrm{L}$. & Malus pumila Mill. & Populus alba L. & Nerium oleader L. \\
\hline Malus baccata (L.) Borkh. & Prunus avium $\mathrm{L}$. & Ulmus americana $\mathrm{L}$. & \\
\hline Pistacia vera $\mathrm{L}$ & Prunus cerasus L. & & \\
\hline Prunus armeniaca L. & Prunus cerasifera J.F. Ehrh. & & \\
\hline Prunus dulcis Mill. & Prunus domestica $\mathrm{L}$. & & \\
\hline Prunus persica (L.) Batsch. & Pyrus calleryana Decne. & & \\
\hline \multirow[t]{4}{*}{ Prunus salicina Lindl. } & Pyrus communis L. & & \\
\hline & Pyrus pyrifolia (Burm.f.) Nakai & & \\
\hline & Quercus suber L. & & \\
\hline & Vitis vinifera L. & & \\
\hline
\end{tabular}


Sodium dihydrogen phosphate greatly advanced the onset of leaf abscission, but the ion that was most active in the abscission response remained unknown. To determine the active ion, several forms of $\mathrm{Na}$ and $\mathrm{P}$ were tested at $0.25,2.5$, and $25 \mathrm{~mm}$. Although all compounds tested at $25 \mathrm{~mm}$ induced olive leaf abscission, only $\mathrm{P}$ sources gave the rapid and significant effects at 0.25 or $2.5 \mathrm{~mm}$ (Fig. 2).

Thirty-two species representing 22 genera were treated with stem-fed $25 \mathrm{~mm} \mathrm{NaH} \mathrm{PO}_{4}$. The most rapid leaf abscissionoccurring without deleterious visual symptoms such as chlorosis, desiccation, or leaf curling-was found with Actinidia, Feijoa, Olea, Populus, and Ulmus (Table 1). All other species showed a range of responses including leaf desiccation, death, white exudate on leaf petiole, and no leaf abscission. In these other species, $25 \mathrm{~mm}$ $\mathrm{NaH}_{2} \mathrm{PO}_{4}$ could have been phytotoxic; lower concentrations were not tested, nor was xylem plugging determined.

We hypothesized that the rapid olive leaf abscission that occurs without leaf chlorosis after $\mathrm{P}$ is stem-fed was due to its accumulation in the explant and its subsequent induction of ethylene synthesis. With $25 \mathrm{~mm} \mathrm{NaH}_{2} \mathrm{PO}_{4}$, olive leaf abscission occurs within 2 days of stem feeding (Fig. 3). Phosphorus concentration in bark and wood below leaves reached a maximum within 2 days of P stem feeding (Fig. 4). In leaf blades, P concentration leveled off by day 3 . In contrast, petiole $\mathrm{P}$ accumulation continued linearly for 4 days to the end of the experiment. Because the leaf abscission zone is found where the petiole attaches to the shoot, the amount and rate of $\mathrm{P}$ accumulation in the petiole was thought to bear directly on the abscission mechanism.

If ethylene production in P stem-fed olive explants caused leaf abscission, then the elevated ethylene evolution should occur well before abscission. We have shown previously that explants must be exposed to ethylene gas $\approx 96 \mathrm{~h}$ before leaf abscission (Lavee and Martin, 1981a-c). Also, in field experiments, fruit or leaf abscission is not apparent for $\approx 7$ days after ethephon treatment (Martin et al., 1981). Measuring ethylene evolution after P stem feeding did not correlate closely with the leaf abscission response (Figs. 3 and 5). In fact, ethylene evolution seems to parallel rather than precede leaf abscission. Even more important, the amount of ethylene measured ( $<50 \mathrm{ppb}$ per container with leaves enclosed) may have been too low to influence leaf abscission. Our previous experiments have shown that 3 to $5 \mathrm{ppm}$ ethylene are required in a closed system for at least $28 \mathrm{~h}$ to induce leaf abscission, which would occur $\approx 96 \mathrm{~h}$ later (Lang and Martin, 1989); thus, rates at $\leq 50 \mathrm{ppb}$ in an open system are unlikely to induce leaf abscission. Even when explants were stem-fed $500 \mathrm{mg} / \mathrm{liter}$ ethephon for $6 \mathrm{~h}, \approx 54 \mathrm{~h}$ elapsed before all leaves abscissed (Lavee and Martin, 1981a). Other researchers using tomato pericarp disks, apple slices, or microorganisms showed that phosphate concentrations greater than $\approx 200 \mathrm{~mm}$ inhibited ethylene production (Fuchs et al., 1981; Sobolewska and Plich, 1986).

Ethephon contains $\mathrm{P}$, and we were interested in determining to what extent the $\mathrm{P}$ in ethephon might contribute to olive leaf abscission. $\mathrm{Al}_{2} \mathrm{O}_{3}$ was added to $\mathrm{NaH}_{2} \mathrm{PO}_{4}$ and ethephon solutions to adsorb phosphate in stem-feeding experiments. When either 25 $\mathrm{mm} \mathrm{NaH} \mathrm{PO}_{4}$ or $200 \mathrm{mg}$ ethephon/liter was used alone and fed continuously, all leaves abscissed by 6 and 3 days, respectively (Fig. 6). When $500 \mathrm{mg} \mathrm{Al} \mathrm{O}_{3} / \mathrm{ml}$ was added to each compound, all leaves abscissed in 13 and 11 days, respectively. The $\mathrm{Al}_{2} \mathrm{O}_{3}$ reacts with phosphate; thus, we assumed that $\mathrm{Al}_{2} \mathrm{O}_{3}$ adsorbed phosphate as ethephon broke down to release ethylene. Clearly, P, even in ethephon, contributes to olive leaf abscission. Additional evidence of the role of $\mathrm{P}$ from ethephon in leaf abscission was gained by adjusting ethephon to $\mathrm{pH} 7$ with $\mathrm{NaOH}$ to drive off the ethylene

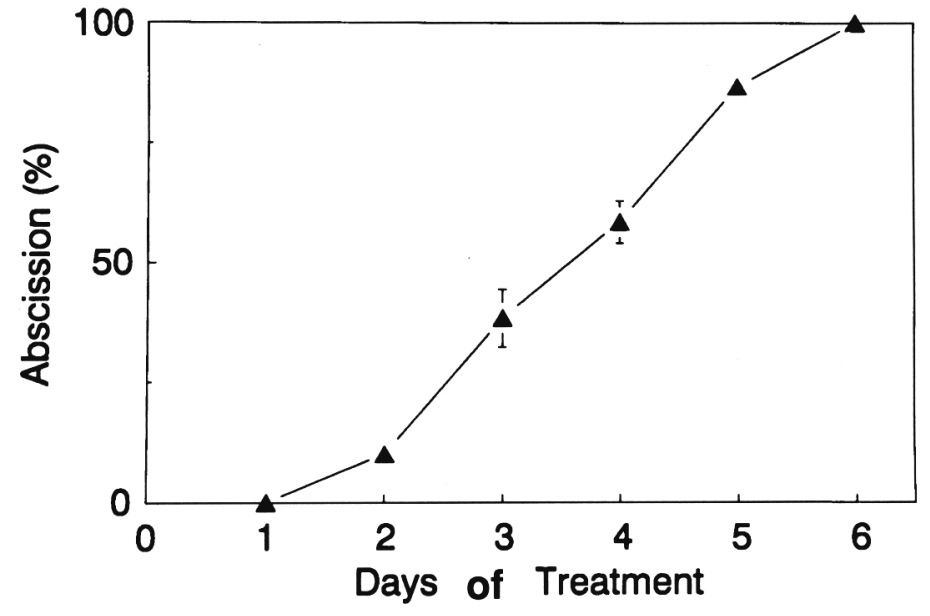

Fig. 3. Effect of stem feeding $25 \mathrm{mM} \mathrm{NaH}_{2} \mathrm{PO}_{4}$ at $\mathrm{pH} 5$ on 'Manzanillo' olive leaf abscission from excised shoots. Vertical bars indicate an SE that exceeds the height of the markers at days 3 and 4 only.

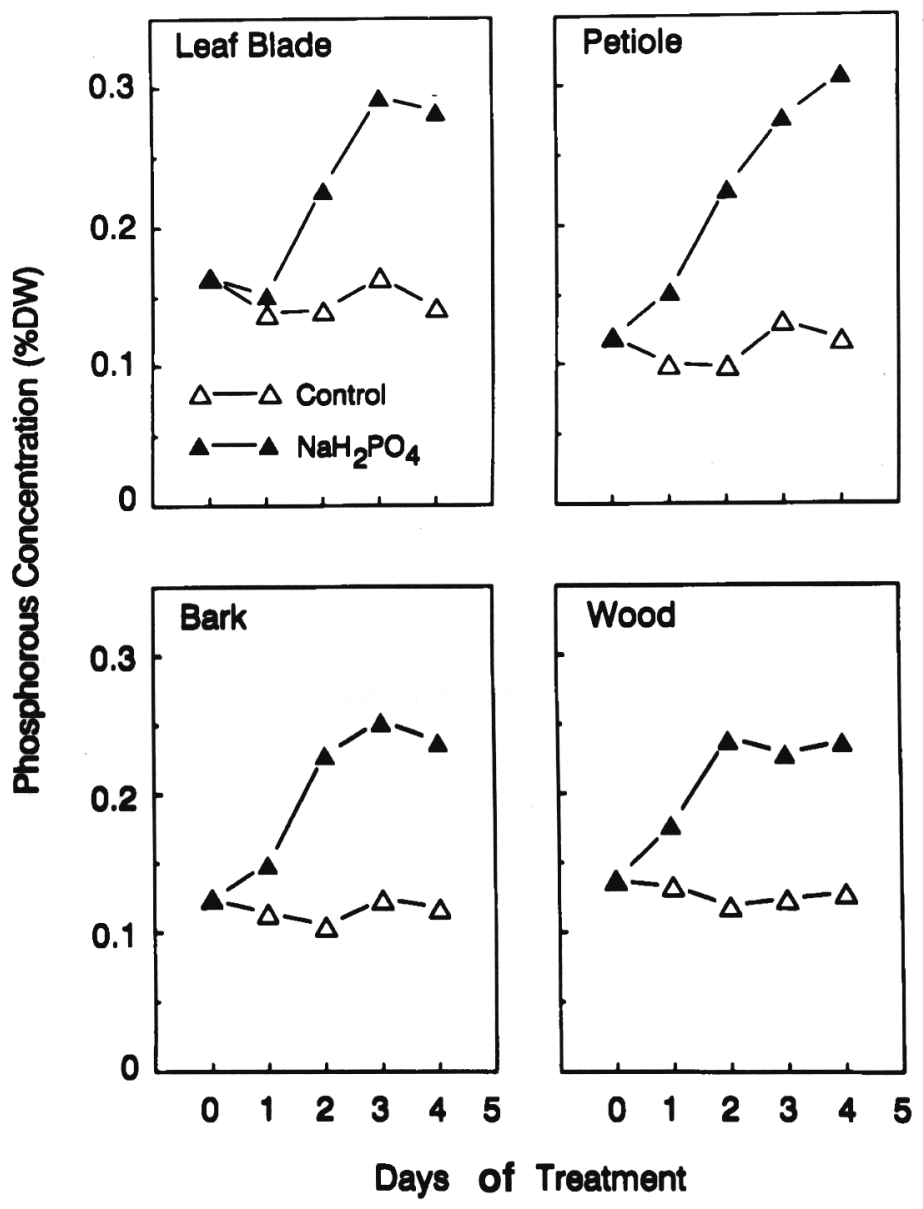

Fig. 4. Effect of stem feeding $25 \mathrm{mMNaH}_{2} \mathrm{PO}_{4}$ at $\mathrm{pH} 5$ on $\mathrm{P}$ concentration in portions of excised olive shoots. SES were smaller than the height of the triangle markers.

(ethylene in ethephon is stable at $\mathrm{pH} 3$ ). Ethephon was allowed to evolve ethylene for 4 days after being adjusted to $\mathrm{pH} 7$ before the solution was stem-fed to explants. The amount of $\mathrm{P}$ remaining in the ethephon solution after driving off ethylene was calculated at $1.38 \mathrm{~mm}$, if all ethylene was evolved from the ethephon molecules. Even this low amount of $\mathrm{P}$ was sufficient to induce leaf abscission (Fig. 6). Although not shown, $500 \mathrm{mg} \mathrm{Al}_{2} \mathrm{O}_{3} / \mathrm{ml}$ did not induce leaf abscission. 


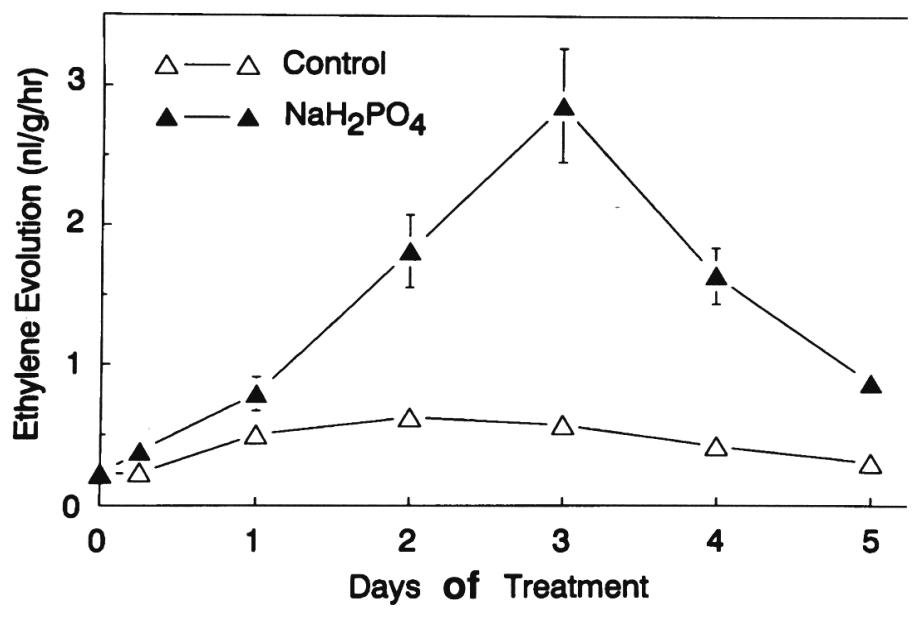

Fig. 5. Effect of stem feeding $\mathrm{NaH}_{2} \mathrm{PO}_{4}$ at $\mathrm{pH} 5$ to excised shoots on ethylene evolution from 'Manzanillo' olive leaves. Vertical bars indicate an SE that does not exceed the height of the triangle markers in some cases.

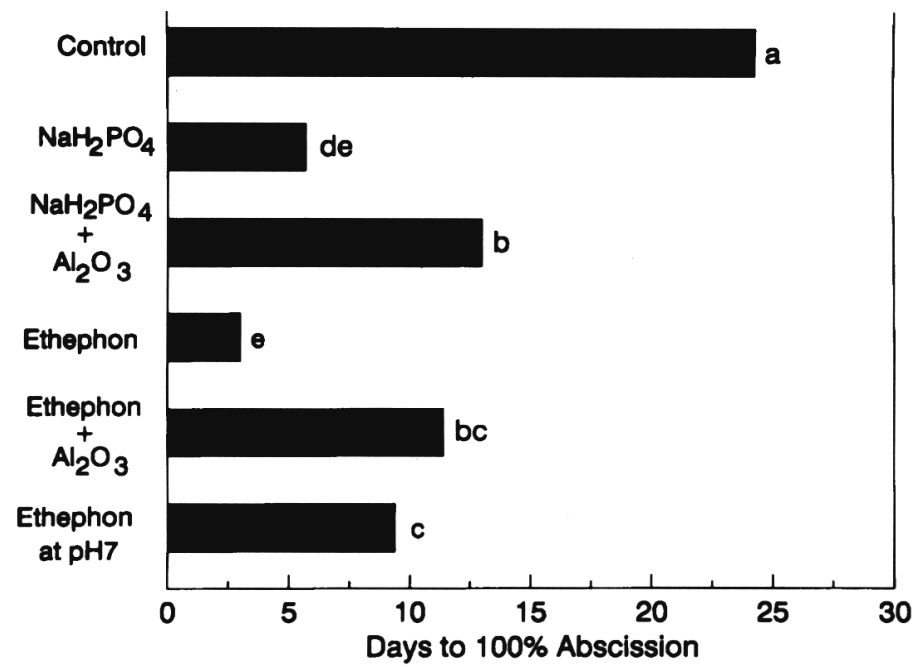

Fig. 6. Effect of stem feeding $25 \mathrm{~mm} \mathrm{NaH2PO4}$ at $\mathrm{pH} 5$ or $200 \mathrm{mg}$ ethephon/liter at $\mathrm{pH} 3$ with and without adding $500 \mathrm{mg} / \mathrm{ml} \mathrm{Al}_{2} \mathrm{O}_{3}$ on 'Manzanillo' olive leaf abscission from excised shoots. Mean separation by Duncan's multiple range test at $P \leq 0.05$.

Explants with fruit were sampled and treated monthly starting Aug. 1991. The data presented in Figs. 7-10 are from late September and early October and are typical of results from similar experiments repeated in each one of the 3 months. The data selected for publishing represent the normal harvest months for California olive (Sibbett et al., 1986).

When stem-fed, $25 \mathrm{~mm} \mathrm{NaH} \mathrm{PO}_{4}$ or $200 \mathrm{mg}$ ethephon/liter led to rapid leaf and fruit abscission (Fig. 7). At a lower $\mathrm{NaH}_{2} \mathrm{PO}_{4}$ concentration or with $\mathrm{Al}_{2} \mathrm{O}_{3}$ added to ethephon, leaf and fruit abscission was delayed (Fig. 7). When ethylene was driven from ethephon by 4 days of treatment at $\mathrm{pH} 7(\mathrm{NaOH})$, subsequent explant treatment with the ethylene-free solution led to delayed leaf and fruit abscission. In the latter case, we suspect abscission was induced by the phosphate residue in the original ethephon solution and any remaining ethylene. Note that the amount of leaf and fruit abscission from the ethephon at $\mathrm{pH} \mathrm{7,} \mathrm{with} \mathrm{a} \mathrm{calculated}$ $1.38 \mathrm{~mm} \mathrm{P}$ content, and that of $2.5 \mathrm{~mm} \mathrm{NaH} \mathrm{PO}_{4}$ was similar (Fig. 7).

Explants with fruit were sprayed with 100,250 , or $500 \mathrm{~mm}$ $\mathrm{NaH}_{2} \mathrm{PO}_{4}$ or $500 \mathrm{mg} /$ liter ethephon. These concentrations were chosen after preliminary experiments showed that higher concentrations of the chemicals were required to cause abscission via foliar sprays than stem-feeding. The higher concentrations may be required, since the thick waxy overlapping peltate trichomes may reduce the penetration of the chemicals into olive leaves or fruit (Weis et al., 1988). Extensive leaf and fruit abscission resulted from ethephon sprays (Fig. 8). In contrast, even $500 \mathrm{~mm} \mathrm{NaH} \mathrm{PO}_{4}$ induced $<25 \%$ leaf abscission, while fruit abscission was equal to that obtained with ethephon. This result supports our notion that $\mathrm{NaH}_{2} \mathrm{PO}_{4}$ and ethephon may induce fruit abscission by collecting in the pedicel-fruit basin, resulting in greater absorption, whereas no such pooling site is available on a leaf. Also, we conjectured that the polar $\mathrm{NaH}_{2} \mathrm{PO}_{4}$ molecules would penetrate the leaf surface less than the nonpolar ethephon molecules. The contrast in leaf and fruit morphology may be exploited, as the anatomical details of olive leaf and fruit abscission processes are similar (Polito and Lavee, 1980; Reed and Hartmann, 1976; Weis et al., 1988, 1991).

Even $25 \%$ olive leaf abscission at harvest is thought to be excessive, to reduce flowering the next year, and to increase the entry of olive knot bacteria at leaf scars (Martin, 1986). Lower concentrations of $\mathrm{NaH}_{2} \mathrm{PO}_{4}$ as single and double sprays (after the first spray dried) and adding glycerol to $\mathrm{NaH}_{2} \mathrm{PO}_{4}$ to prolong drying time and increase the opportunity for chemical penetration

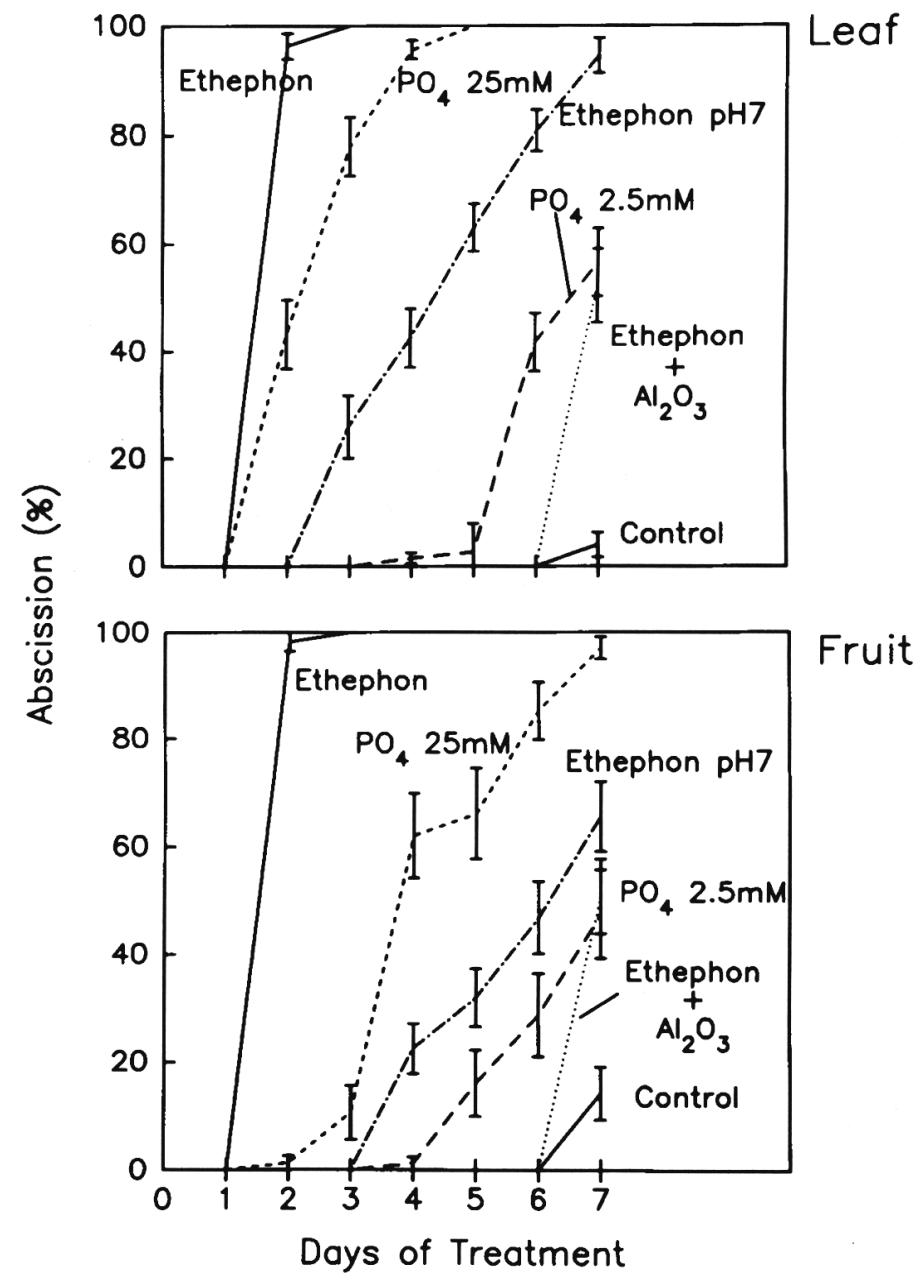

Fig. 7. Effects of stem feeding $25 \mathrm{mM} \mathrm{NaH}_{2} \mathrm{PO}_{4}$ at pH 5 and $200 \mathrm{mg}$ ethephon/liter at $\mathrm{pH} 3$ on 'Manzanillo' leaf and fruit abscission from excised shoots. Vertical bars indicate the SE of the mean. 
into the fruit abscission were tested. Whereas $500 \mathrm{mg}$ ethephon/ liter led to extensive leaf and fruit abscission (Fig. 8), 50 or $100 \mathrm{~mm}$ $\mathrm{NaH}_{2} \mathrm{PO}_{4}$ caused $<10 \%$ leaf abscission and $\approx 50 \%$ fruit abscission in 7 days (Fig. 9). Adding glycerol to $100 \mathrm{~mm} \mathrm{NaH}_{2} \mathrm{PO}_{4}$ increased leaf and fruit abscission to $\approx 10 \%$ and $75 \%$, respectively. Although not shown on the figure because of data overlap, $50 \mathrm{~mm} \mathrm{NaH}_{2} \mathrm{PO}_{4}$ sprayed twice gave results similar to those obtained with the single $100 \mathrm{~mm} \mathrm{NaH}_{2} \mathrm{PO}_{4}$ treatment.

These results were promising, as it began to appear that a commercial treatment strategy to treat olive trees in the field using $\mathrm{NaH}_{2} \mathrm{PO}_{4}$ could be designed for minimal leaf loss and sufficient fruit loosening. To further test our hypothesis regarding spray accumulation in the pedicel-fruit cavity, ethephon and $\mathrm{NaH}_{2} \mathrm{PO}_{4}$ were applied as sprays or by filling the pedicel-fruit cavity with $30 \mu \mathrm{l}$ of spray solution. Both (as spray or cavity treatment) $500 \mathrm{mg} / \mathrm{liter}$ ethephon and $100 \mathrm{~mm} \mathrm{NaH}_{2} \mathrm{PO}_{4}$ led to $80 \%$ and $60 \%$ fruit abscission, respectively (Fig. 10). In contrast, $30 \mu \mathrm{l}$ of $500 \mathrm{mg} / \mathrm{liter}$ ethephon or $100 \mathrm{~m} \mathrm{M}$ $\mathrm{NaH}_{2} \mathrm{PO}_{4}$ solution applied to the petiole led to $20 \%$ and $10 \%$ leaf abscission, respectively. The solution-collection advantage of the pedicel-fruit cavity and its subsequent greater absorption clearly led to greater fruit than leaf abscission (Fig. 10).

There are several practical reasons to continue this research. Phosphorus routinely is used as a fertilizer and a food additive; thus, Environmental Protection Agency clearance should be easy to obtain. The cost of $\mathrm{P}$ treatment for olive fruit loosening will not be prohibitive. The polar nature of inorganic $\mathrm{P}$ allowed it to penetrate better in the pedicel-fruit attachment zone than in the leaf, as shown in our results. Still, it is evident that, should sufficient $P$ penetrate leaf surfaces, excessive leaf abscission could occur. Devising means to maximize fruit abscission while minimizing leaf abscission remains to be achieved.

The response range of plant species to $\mathrm{P}$ should be explored in detail. Selective breeding for plants able to cope with low or high $\mathrm{P}$ may be possible. Also, unaccountable flower abscission reported for many crops may be an expression of sensitivity to high $\mathrm{P}$ content during the bloom and postbloom periods of development. The mechanism of $\mathrm{P}$ leaf abscission remains obscure.

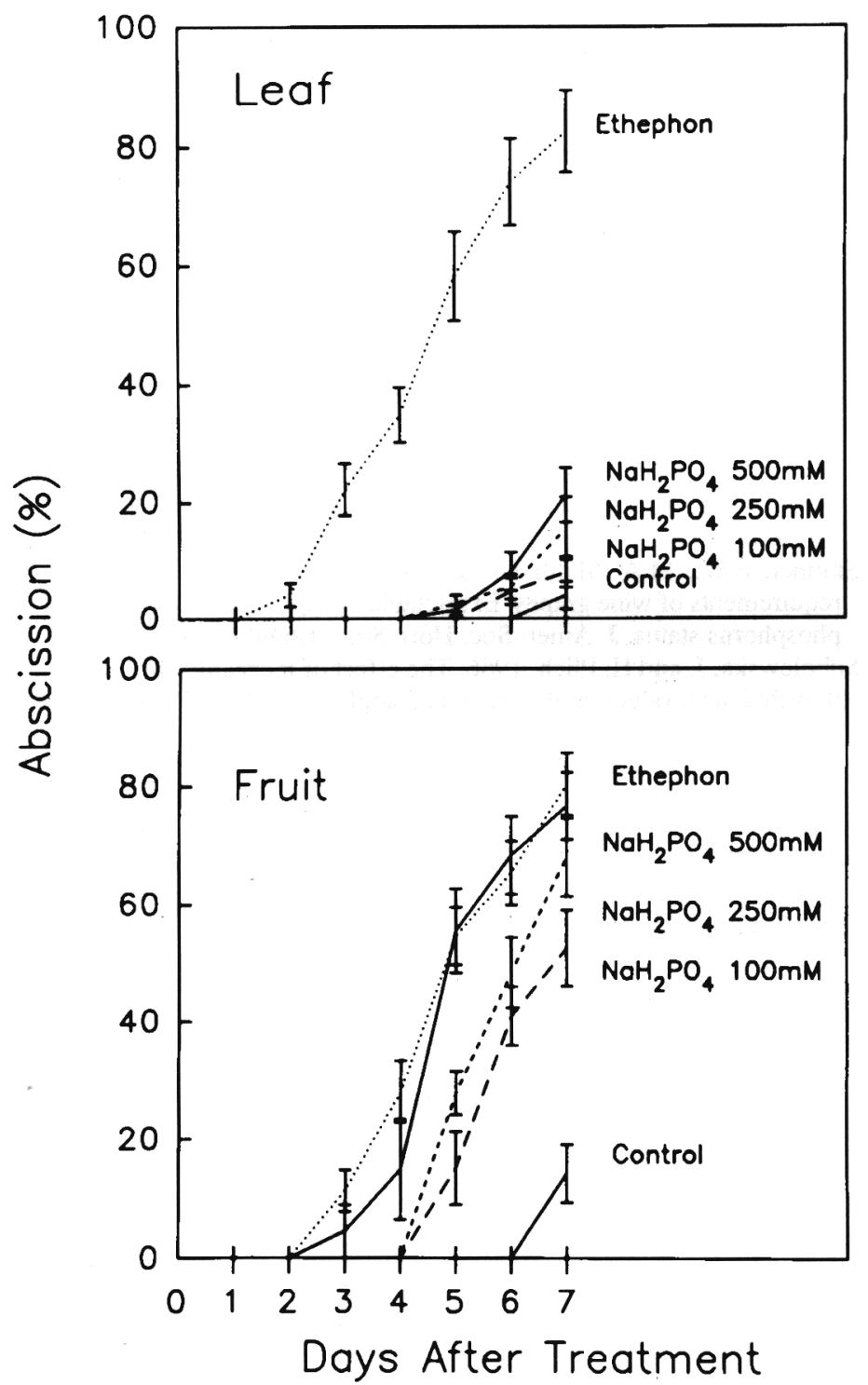

Fig. 8. Effects of foliar application of $500 \mathrm{mg}$ ethephon/liter at $\mathrm{pH} 3$ and $\mathrm{NaH}_{2} \mathrm{PO}_{4}$ at several concentrations at $\mathrm{pH} 5$ on 'Manzanillo' leaf and fruit abscission from excised shoots. Vertical bars indicate the SE of the mean.

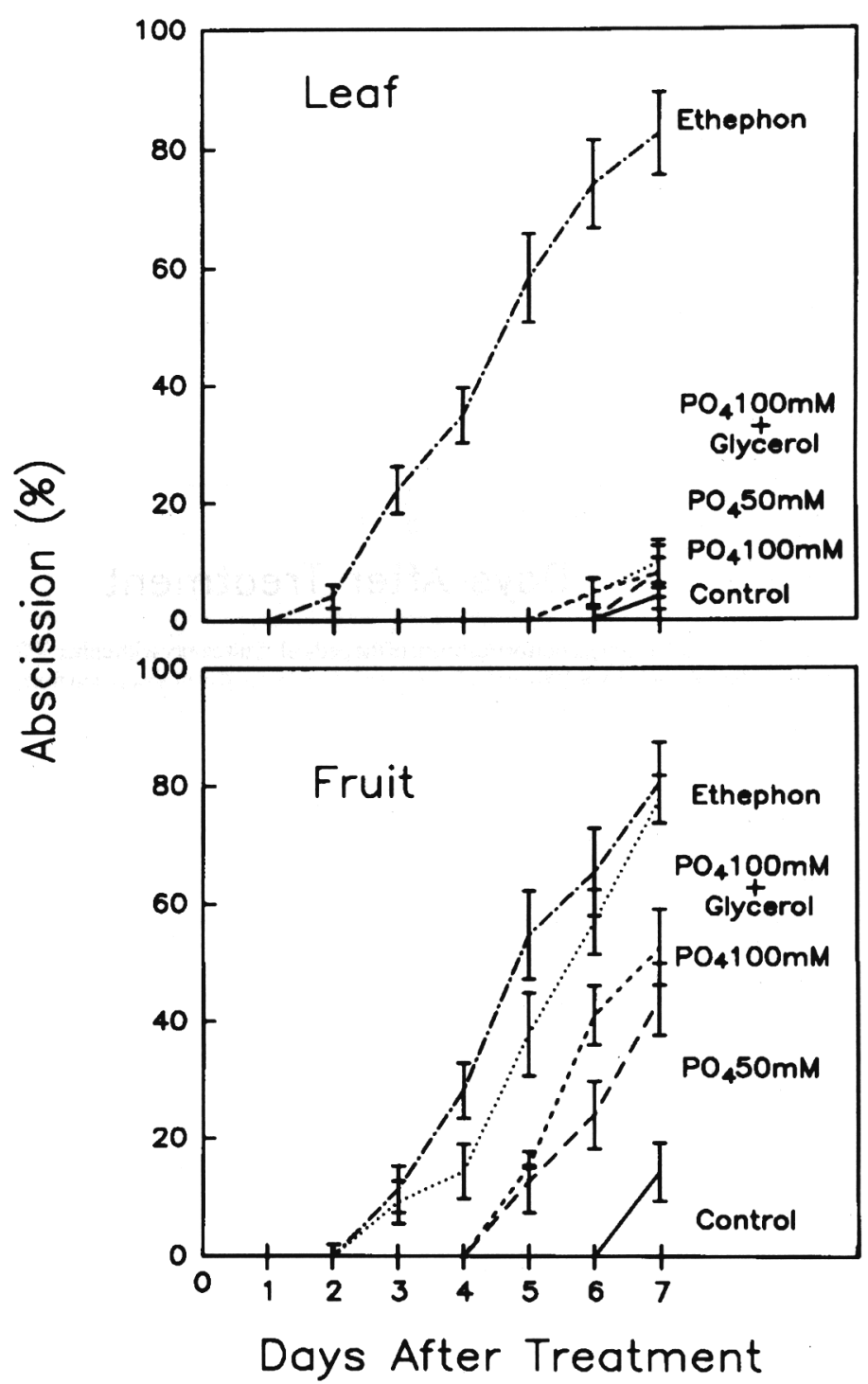

Fig. 9. Effects of $500 \mathrm{mg}$ ethephon/liter compared to glycerol and single or double applications of $\mathrm{NaH}_{2} \mathrm{PO}_{4}$ as foliar sprays on leaf and fruit abscission from excised 'Manzanillo' olive shoots. Vertical bars indicate the SE of the mean. 


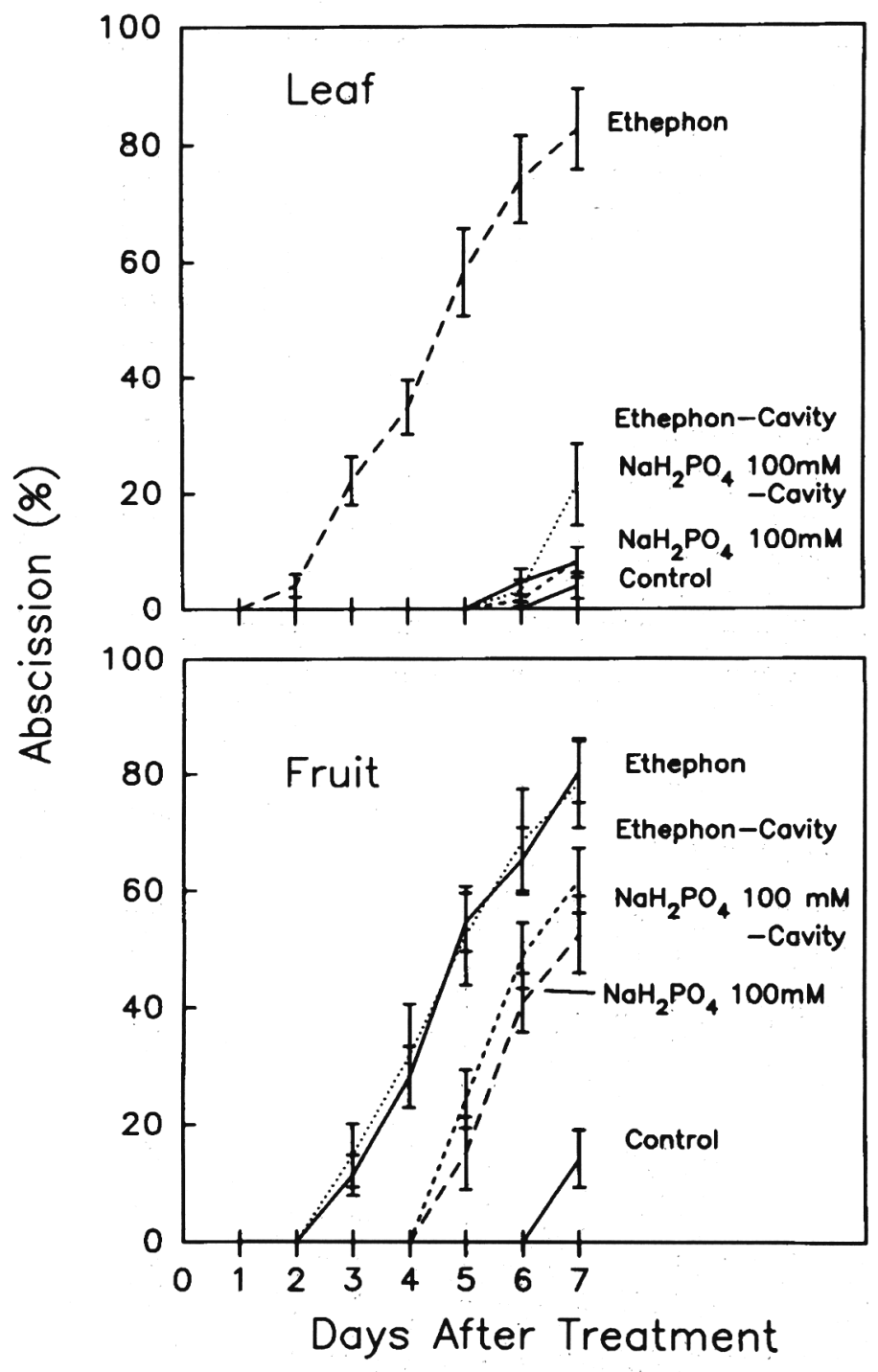

Fig. 10. Effects of foliar application or treatment of the pedicel-fruitcavity with either 500 $\mathrm{mg} /$ liter ethephon at $\mathrm{pH} 3$ or $100 \mathrm{~mm} \mathrm{NaH}_{2} \mathrm{PO}_{4}$ at $\mathrm{pH} 5$ on leaf and fruit abscission from excised 'Manzanillo' olive shoots. Vertical bars indicate the SE of the mean.

\section{Literature Cited}

Ben-Tal, Y. and S. Lavee. 1976. Increasing the effectiveness of ethephon for olive harvesting. HortScience 11:489-490.

Daniell, J.W. and R.E. Wilkinson. 1972. Effect of ethephon-induced ethylene on abscission of leaves and fruits of peaches. J. Amer. Soc.
Hort. Sci. 97:682-685.

Elliot, G.C., R.M. Carlson, A. Lauchli, and C.J. Rosen. 1983. A solid phase buffer technique to maintain low concentrations of phosphate in nutrient solutions. J. Plant Nutr. 6:1043-1058.

Fisher, E.G. and D.R. Walker. 1955. The apparent absorption of phosphorus and magnesium from sprays applied to the lower surface of McIntosh apple leaves. Proc. Amer. Soc. Hort. Sci. 65:17-24.

Fuchs, Y., A.K. Mattoo, C. Chalutz, and I. Rot. 1981. Biosynthesis of ethylene in higher plants: The metabolic site of inhibition by phosphate. Plant, Cell \& Environ. 4:291-295.

Lang, G.A. and G.C. Martin. 1985. Ethylene-releasing compounds and the laboratory modelling of olive fruit abscission versus ethylene release. J. Amer. Soc. Hort. Sci. 110:207-211.

Lang, G.A. and G.C. Martin. 1989. Olive organ abscission: Fruit and leaf response to applied ethylene. J. Amer. Soc. Hort. Sci. 114:134-138.

Lavee, S. and G.C. Martin. 1981a. In vitro studies on ethephon-induced abscission in olive. I. The effect of application period and concentration on uptake, ethylene evolution, and leaf abscission. J. Amer. Soc. Hort. Sci. 106:14-18.

Lavee, S. and G.C. Martin. 1981b. In vitro studies of ethephon-induced abscission in olive. II. The relationship between ethylene evolution and abscission of various organs. J. Amer. Soc. Hort. Sci. 106:19-26.

Lavee, S. and G.C. Martin. 1981c. Ethylene evolution following treatment with 1-aminocyclopropane-1carboxylic acid and ethephon in an in vivo olive shoot system in relation to leaf abscission. Plant Physiol. 67:1204-1207.

Martin, G.C. 1986. Olive harvest in California, United States of America. Olivae 3:11-20.

Martin, G.C., S. Lavee, and G.S. Sibbett. 1981. Chemical loosening agents to assist mechanical harvest of olive. J. Amer. Soc. Hort. Sci. 106:325-330.

Polito, V.S. and S. Lavee. 1980. Anatomical and histochemical aspects of ethephon-induced leaf abscission in olive (Olea europaea L). Bot. Gaz. 141:413-417.

Reed, N.R. and H.T. Hartmann. 1976. Histochemical and ultrastructural studies of fruit abscission in olive after treatment with 2-chlorethyl-tris-(2-methoxyethoxy)-silane. J. Amer. Soc. Hort. Sci. 101:633-637.

Sibbett, G.S., M.W. Freeman, L. Ferguson, D. Anderson, and G. Welch. 1986. Timing Manzanillo olive harvest for maximum profit. Calif. Agr. 40:19-22.

Skinner, P.W., M.A. Matthews, and R.M. Carlson. 1987. Phosphorus requirements of wine grapes: Extractable phosphate of leaves indicates phosphorus status; J. Amer. Soc. Hort. Sci. 112:449-454.

Sobolewska, J. and H. Plich. 1986. The effect of inorganic phosphate on the ethylene production in tomato and apple fruits. Biol. Plant (Prague) 28:95-99.

Weis, K.G., B.D. Webster, R. Goren, and G.C. Martin. 1991. Inflorescence abscission in olive: Anatomy and histochemistry in response to ethylene and ethephon. Bot. Gaz. 152:51-58.

Weis, K.G., R. Goren, G.C. Martin, and B.D. Webster. 1988. Leaf and inflorescence abscission in olive. I. Regulation by ethylene and ethephon. Bot. Gaz. 149:391-397. 